\title{
Aliphatic hydrocarbon biomarkers of Sekar Kurung Gresik crude oil
}

\author{
Dyah Nirmala $^{\text {a }, ~ R . ~ Y . ~ P e r r y ~ B u r h a n ~}{ }^{a,{ }^{*}}$,Suprapto ${ }^{\text {b, }}$, Yulfi Zetra ${ }^{a}$ \\ a Molecular Geochemistry Laboratory, Department of Chemistry, Faculty of Mathemathics and Science, Institut Teknologi Sepuluh Nopember, \\ Kampus ITS Sukolilo, Surabaya 60111, Indonesia \\ ${ }^{b}$ Department of Chemistry, Faculty of Mathemathics and Science, Institut Teknologi Sepuluh Nopember, Kampus ITS Sukolilo, Surabaya 60111, \\ Indonesia \\ *Corresponding author: pburhan@chem.its.ac.id ; pburhan@gmail.com
}

Article history

Received 28 January 2018

Revised 7 August 2018

Accepted 3 September 2018

Published Online 25 June 2019

\begin{abstract}
Characterization of petroleum biomarker from Sekar Kurung Gresik, was carried out to investigate its organic composition, depositional environment and oil maturity. The oil sample was extracted and fractionated using column chromatography to derive aliphatic hydrocarbon fraction. The aliphatic hydrocarbon compounds were analyzed using gas chromatography-mass spectrometer (GC-MS). The GC-MS analysis shows that $n$-alkanes compound $\left(\mathrm{C}_{14}-\mathrm{C}_{28}\right)$, isoprenoid alkanes $\left(\mathrm{iC}_{15} \mathrm{iC}_{16}\right.$ and $\mathrm{iC}_{18}-\mathrm{iC}_{20}$ ), a bicyclic sesquiterpene, eudesmane, cadinane, hopane, bicadinane, gammacerane and diasterane were observed. The identified compounds show that the crude oil compounds were derived from terrestrial higher plants, the contribution of bacterial activity and the oxic deposition environment $(\mathrm{Pr} / \mathrm{Ph}=5.3(<1))$. The oil analyzed is a mature oil.
\end{abstract}

Keywords: Biomarker, crude oil, aliphatic hydrocarbon

\section{INTRODUCTION}

Petroleum is a complex compound of hydrocarbons that are naturally occuring in the gas phase (natural gas), liquid (crude oil) and solid (asphalt). Petroleum was derived from a variety of organic materials that were chemically converted over a long period (hundreds of millions of years) under various heat and geological conditions. Crude oil is a mixture of solid and liquid that is made of carbon and hydrogen, but also a small amount of sulfur, oxygen, nitrogen, and small amount of metal (such as nickel and vanadium) [1].

Petroleum geochemistry is an essential science in understanding a petroleum system. Source rocks may be directly sampled and analyzed to reveal their source potential and thermal maturity. Extracted bitumens from naturally and artificially matured source rocks are then compared with oils, providing a direct correlation [2].

Assesment of geochemical organic was conducted based on the behavior of the fossils compound (biomarker). Biomarker is a complex biological molecular compounds derived from living organisms that have died. These compounds retain the basic framework of the source of biosynthesis origin in living organisms, but has undergone a change of it's functional groups, break of the bond and changes of stereochemistry that occur as a result of conditions in the bowels of the earth, such as the presence of thermal and pressure changes [3]. Many compounds in petroleum and other fossil fuels are unambiguosly biomarkers. The most common and widely studied are acyclic isoprenoids, selected branched alkanes, cyclic terpenoids and steroids.

Immature bitumens consist of unsaturated and functionalized compound that frequently present under thermal conditions. Biomarker may also contain heteroatoms such as sulfur which may become incorporated into the above mentioned biomarker during early diagenesis under anoxic, marine conditions. Acid by-products from microbial degradation, and porphyrins containing nitrogen and metals are common in low maturity oils [2].
The existence of this biomarker deliver information about the complex molecules that occurs in source rocks, which are obtained from organic compounds precursor biomarker contained in various living organisms. The compound also provides information on the maturity, their biodegradation, migration in sediments and petroleum [4], the origin of organic material, depositional environment and quality of oil [5]. Biological precursor compounds, may also provide the information about the picture of the geochemical processes that take place in the sediment at different stages of maturation [6].

In general, the presence of biomarkers in an oil can be distinguished over aliphatic and aromatic hydrocarbons groups. Biomarkers on aliphatic hydrocarbons can be found in the form of $n$ alkanes, acyclic isoprenoid, bicyclic sesquiterpene and polycyclic terpenoids. The distribution of $n$-alkanes biomarkers compounds in petroleum sample can deliver information about the types of sources and the maturity level of petroleum [7]. Pristane and phytane ratio which is specifically isoprenoid compounds can potentially be used to determine the environmental conditions i.e. oxidative or reductive deposition during the deposition process of organic material [8]. The existence of polycyclic terpenoids compounds indicate the origin of the organic material and the degree of biodegradation of petroleum marker [9].

Aliphatic hydrocarbons are the most important group of biomarker compounds. This group of compounds can provides information regarding the characteristics of a crude sample, for example an oilforming precursor formed from naflagellates has high abundance of the alkane short chain [7]. The type of oil that originated from the marine environment was indicated by the unimodal distribution of n-alkane compounds ( $n-\mathrm{C}_{16}-n-\mathrm{C}_{23}$ ). Deposition environment of oil derived from reductive environments was by the present of pristane and phytane compounds [10].

The purpose of this study was to identify and characterize aliphatic hydrocarbon fraction biomarkers Sekar Kurung crude oil Gresik. Sekar Kurung Gresik is situated in the East Java Basin, north region of 
Rembang which spread from Tuban eastward through Lamongan, Gresik, and almost the entire island of Madura. This basin formed in the Late Oligocene trending east - west parallel to Java. The hallmark of this Rembang zone is the deposition from shelf to the rich in carbonates and material mainland (terrigeneous), as well as the deposition of sediments from the shallow sea not far from shore at a depth of the seabed is not uniform [11].

\section{EXPERIMENTAL}

\section{Materials}

Samples of crude oil from Sekar Kurung Gresik, aquabidest, acetone p.a., dichloromethane p.a., $n$-hexane p.a., cotton, silica gel, sea sand, cellite, chloroform p.a., isopropanol, potassium hydroxide, diethyl ether p.a., formic acid p.a. chloroform, methanol p.a, dibenzoanthracene, nitrogen gas, copper powder, parafilm and aluminum foil.

\section{Instrumentation}

A set of equipment i.e. soxhlet apparatus, analytical balance, tulips funnel, rotary evaporator, heating mantle, TLC plate, beaker glass, flask, fractionation column, tweezers, measuring cups, pumpkin round, separating funnel, TLC chamber, vial bottle, spray bottle, spatula, pipette, pasteur pipette and a set of distillation equipment, column chromatography, gas-chromatography mass spectrometry (GC-MS).

\section{Extraction and fractionation}

Crude oil ( $2 \mathrm{~g}$ ) was separated from aspalten by adding excess hexane (at ratio of 1:40), resulting in malten and asphalten fractions. Malten was fractionated by column chromatography method to separate neutral fraction, acid fraction and polar fraction. The first elution was done using diethylether to obtain neutral fractions. Elution was continued using $2 \%$ formic acid in diethyl ether to obtain acid fraction. The last elution was done using a mixture of methanol: chloroform: water $(65: 25: 4)$ to obtain the polar fraction.

The neutral fraction was refracted by Thin Layer Chromatography (TLC) to separate hydrocarbon, alcohol and ketone fraction using dichloromethane eluent. The hydrocarbon fraction obtained was refractionated by TLC method using $n$-hexane to separate the aromatic and aliphatic hydrocarbon fractions. The biomarkers in aliphatic hydrocarbon fraction were analyzed and identified using gas chromatography-mass spectrometer (GC-MS) Shimadzu QP2010S conducted at $50{ }^{\circ} \mathrm{C}(5 \mathrm{~min}), 50{ }^{\circ} \mathrm{C}-300{ }^{\circ} \mathrm{C}\left(10{ }^{\circ} \mathrm{C} /\right.$ minute $)$ and isothermal temperature at $290{ }^{\circ} \mathrm{C}$ for 25 minutes [6].

\section{RESULTS AND DISCUSSION}

\section{Biomarkers of aliphatic hydrocarbon}

Analysis and identification of aliphatic hydrocarbon fraction of Sekar Kurung Gresik crude oil sample indicate the presence of $n$-alkane compounds, isoprenoid alkanes, bicyclic sesquiterpene, eudesmane, cadinane, hopane, bicadinane, gammacerane and diasterane. Identified biomarkers are used to determine the origin of organic matter, the deposition environment and the crude oil maturation.

The result of the GC-MS analysis is shown as total chromatograms in Figure 1.

\section{Biomarkers of $n$-alkane}

$n$-alkane hydrocarbons are the most abundant biomarker found in all types of oil. $n$-alkane hydrocarbons are not biodegradable. One of $n$-alkanes commonly found is $\mathrm{n}$-hexadecane $\left(\mathrm{nC}_{16}\right)$ [12].

The distribution of $n$-alkanes in crude oil can be used to determine the source of organic compounds. Mass spectra of the $n$-alkane hydrocarbon compound was identified had a base peak of $\mathrm{m} / \mathrm{z} 57$ and a pattern of decreasing intensity linearly at $\mathrm{m} / \mathrm{z} 71,85,99$ and so on with addition of 14 (as the release of methylene) (-CH2) (Herod et al., 1995). The presence of $n$-alkanes identified by mass fragmentogram at $m / z 57$, which is the base peak of alkanes compound. The base peak at $\mathrm{m} / \mathrm{z} 57$ is identified as a result of the release of the butyl group $\left(-\mathrm{C}_{4} \mathrm{H}_{9}\right)$.

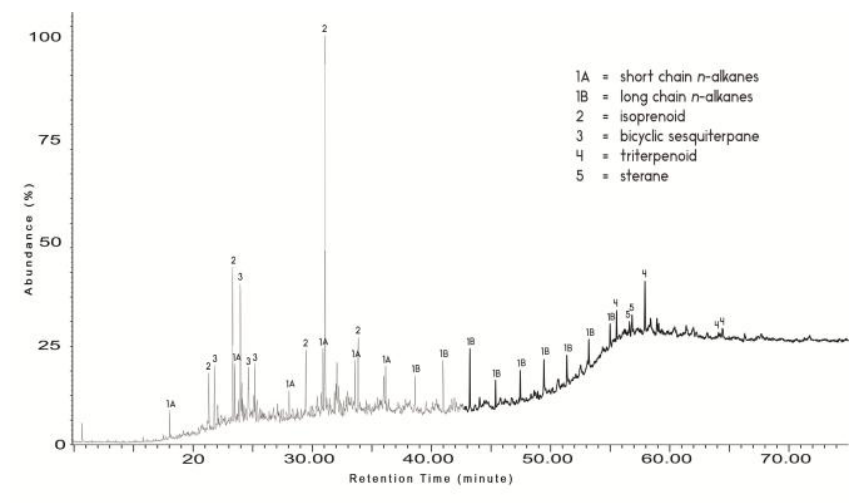

Fig. 1 Total chromatograms of aliphatic fraction from Sekar Kurung Gresik East Java crude oil using GCMS at temperature of $50^{\circ} \mathrm{C}$ (5 minutes $), 50^{\circ} \mathrm{C}-300^{\circ} \mathrm{C}\left(10^{\circ} \mathrm{C} /\right.$ minute $)$ and isothermal temperature at 29 ${ }^{\circ} \mathrm{C}$ for 25 minutes.

General information that can be obtained from the distribution of $n$-alkane compounds is the origin of geological samples that are often found as geological guidance [13]. The presence of short chain $n$ alkanes $(\mathrm{C}<20)$ compounds (Figure.1 at peak 1.A) provide information regarding the contribution of organic matter in the sediments that are derived from algae and bacteria [14], while the long-chain $n$-alkane (C> 20) (Figure 1 at peak 1.B) indicates that the sediment is derived from the wax cuticle on terrestrial higher plants (terrestrial) [15]. The existence of long-chain $n$-alkanes biomarkers compounds were from the mainland of higher plants, wax and woody deposited into the sea was generally carried by the flow of water (river) or through windborne dust flying [16]. It is also stated in the research of Bakar et al (2011), who reported the distribution of long-chain $n$-alkanes in the range of $\mathrm{C}_{21}-\mathrm{C}_{37}$ indicates contribution of organic compound land plants.

The homologous hydrocarbons of $n-\mathrm{C}_{14}-n \mathrm{C}_{28}$ (Figure 1 at peak 1.A and 1.B) indicates that the organic compounds derived from the terrestrial environment and the contribution of microorganisms to the formation process of petroleum organic compounds.

$n$-alkanes in the ranges of $\mathrm{C}_{14}-\mathrm{C}_{28}$ is an indicator of terrestrial (land) plant derived from higher plant. However, the compound with $\mathrm{C}<20$ are less dominating. Sediment that contain homologous $n$-alkanes with carbon range between $\mathrm{C}_{14}$ to $\mathrm{C}_{20}$ and $\mathrm{C}_{17}$ at the maximum peak indicate that the source of the sediment organic matter formed from marine phytoplankton and algae [17]. The contribution of marine phytoplankton and algae as a source of organic matter on Sekar Kurung crude oil is possible because of the geological of Sekar Kurung region that is near the sea.

Distribution of long-chain $n$-alkanes are dominated by $\mathrm{C}_{21}-\mathrm{C}_{28}$, show that the source of sediment's organic matter derived from vascular plant, microalgae, cyanobacteria and aquatic microorganisme, especially macrophytes. Tissot and Walte (1984) also stated that the homologous compound of $n$-alkanes $\mathrm{C}_{25}-\mathrm{C}_{35}$ is a marker compound for sedimentary organic matter source derived from the wax coat of higher plants.

Aliphatic hydrocarbon fraction analysis for the distribution of homologous $n$-alkanes and isoprenoid alkane in fragmentogram $\mathrm{m} / \mathrm{z} 57$ is shown in Figure 2.

\section{Biomarkers of isoprenoid alkanes}

The presence of branched alkane compounds in the aliphatic hydrocarbon fraction is indicated by the increased intensity of $M+-15$ and $\mathrm{M}+-29$ fragments (Figure 3), indicating the presence of a methyl branch in the $\mathrm{C}_{2}$ (iso-alkane) or $\mathrm{C}_{3}$ (anteiso-alkane) alkane chain. There is an increase in abundance in certain fragments (especially at branch termination) resulting in no longer forming a linear pattern, indicating the isoprene pattern [18]. The biomarkers of isoprenoid compounds in the presence of geological samples were used as an indicator to determine the origin of organic materials, characterization and correlation studies to obtain information about the deposition environment. The structure of isoprenoid compounds found in variety 
of old sediments and petroleum with a structure that is still in good condition [12].

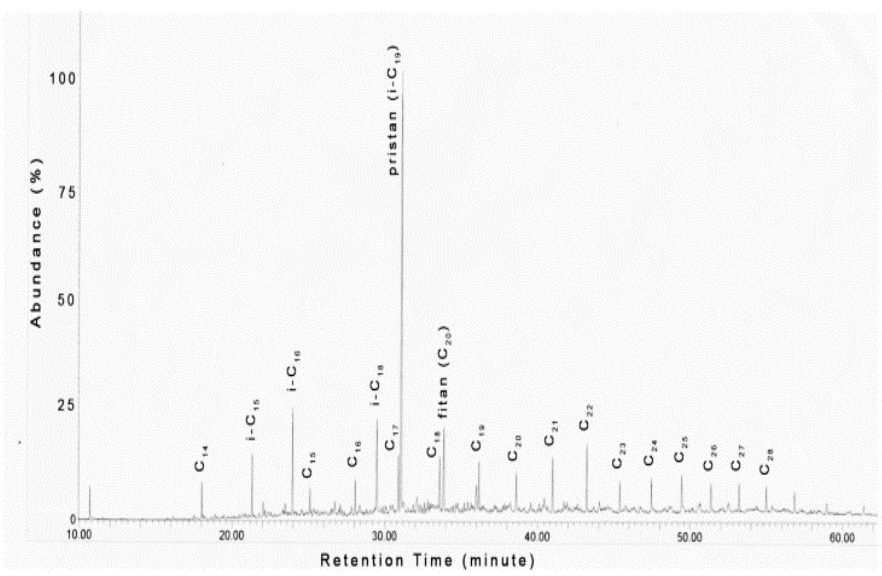

Fig. 2 Fragmentograms of Sekar Kurung Gresik crude oil aliphatic hydrocarbon fraction with $\mathrm{m} / \mathrm{z} 57$.

The existence of isoprenoid biomarkers is identified by fragmentogram at $\mathrm{m} / \mathrm{z} 57$. The analysis result of isoprenoid biomarkers indicate that distribution of alkane isoprenoid compounds are in $\mathrm{C}_{15}$ $\mathrm{C}_{20}$ carbon range. The existence of isoprenoid biomarkers confirmed that the organic matter was derived from phototropic organisms [19]. The results of Soudan, Minnesota and Antrim sediment as well as Nonesuch oil also found the presence of isoprenoid alkane compounds in the range of $\mathrm{C}_{16}$ and $\mathrm{C}_{18}-\mathrm{C}_{20}$. The existence of this compound was originate from the phytol compound which is a side chain of chlorophyl in phototopic organisms.

Pristane and phytane compounds existence can provide the information regarding the deposition environment. If the ratio of $\operatorname{Pr} / \mathrm{Ph}>1$, the deposition environment is oxic, whereas if $\operatorname{Pr} / \mathrm{Ph}<1$, then the depositional environment is anoxic [8]. The formation of compounds derived from the phytane saturation and dehydration reaction are due to diagenetic process. While the oxidation reaction, decarboxylation and saturation of the compounds could produce pristane compound [20]. The ratio of $\mathrm{Pr} / \mathrm{Ph} 5.3$ (> 1) indicates that oil samples were formed under oxic environment conditions. The mass spectra of pristane shown in Figure 3 below:

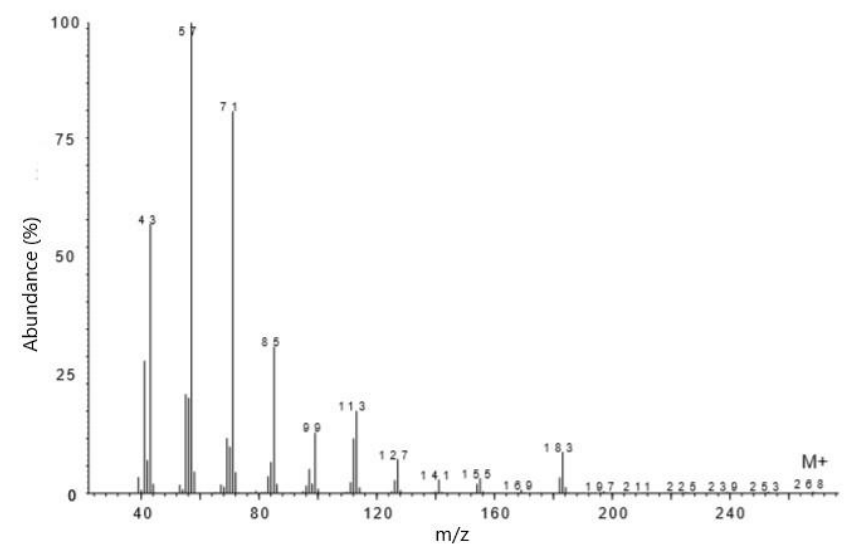

Fig. 3 Mass spectra of pristane $\left(\mathrm{C}_{19} \mathrm{H}_{40}\right)$ from aliphatic hydrocarbon fraction.

\section{Biomarkers of sesquiterpenoid}

Biomarkers of bicyclic sesquiterpenoid are the largest part of terpenoids group. These compounds have been widely studied in crude oil and sediment from various parts of the world but they were not stable [21]. This compound is first reported by Bendoraitis (1974) with the presence of a bicyclic sesquiterpane in Loma Nove biodegrade crude oil from the Gulf Coast of Texas. Furthermore, Philp et.al (1981) and Richardson (1982) reported the distribution of these compounds in the crude oil in Australia and Indonesia. The existence of sesquiterpane indicate the source of the organic compound in oils was originate from higher plants.

The presence of sesquiterpenoid biomarkers is identified by mass fragmentogram at m/z 109 and 123 that shown in Figure 4 below:

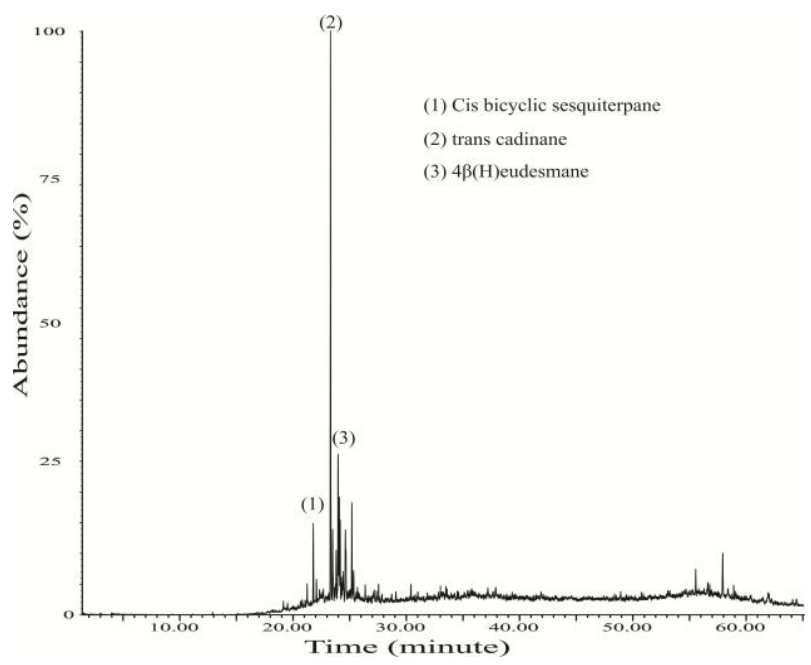

Fig. 4 Mass fragmentogram m/z 109 aliphatic hydrocarbon fraction.

Some of the identified biomarkers such as $\mathrm{C}_{15}$-bicyclic sesquiterpane, $4 \beta(\mathrm{H})$-eudesmane and trans cadinane deliver information that petroleum organic compounds are produced by typical terrestrial plants [22] of the Tertiary Periode [23]. $4 \beta(\mathrm{H})$-eudesmane provide information that petroleum organic compounds were produced by terrestrial plants [22] that were characteristic of the Miocene Period [24]. These compounds have also been found and used as an indication of the high level of plant organic matter in the Middle Miocene Epoch oil sample of Brunei Darussalam [23].

$\mathrm{C}_{15}$ bicyclic sesquiterpenoid, was elucidated from fragment ions at $\mathrm{m} / \mathrm{z} 193$ and 208. The peak of ion fragments were the typical fragment for $C_{15}$-bicyclic sesquiterpane compounds published by Philp (1985). The detection of fragment ions at m/z 193 was the base peak due to the loss of the $\left(\mathrm{CH}_{3}\right)^{+}$group. The molecular ion value detected at $\mathrm{m} / \mathrm{z} 208$ (Fig. 4) shows 2 degrees of unsaturation. This is suitable for the structure of $\mathrm{C}_{15}$ bicyclic sesquiterpane compound having 2 cyclic rings. Thus, the compound obtained is $\mathrm{C}_{15}$ bicyclic sesquiterpene $\left(\mathrm{C}_{15} \mathrm{H}_{28}\right)$. The mass spectra of $\mathrm{C}_{15}$ bicyclic sesquiterpane is shown in Figure 5 below :

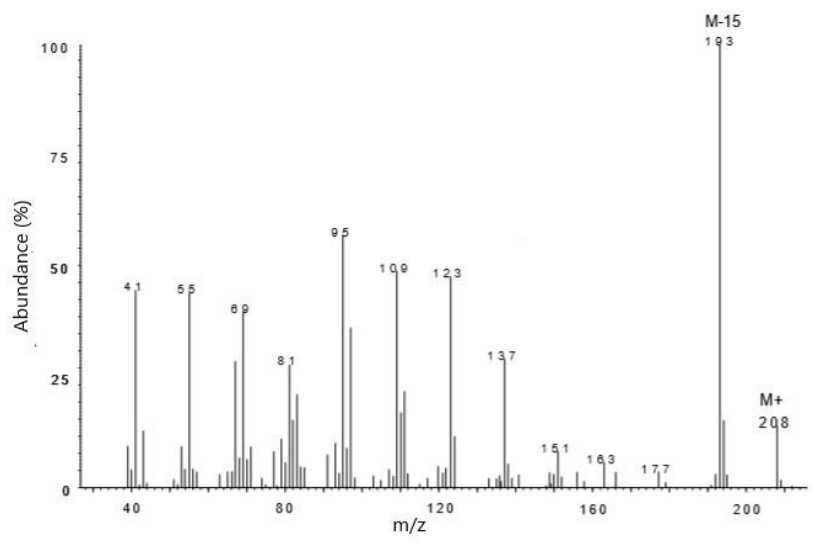

Fig. 5 The peak mass spectrum of $C_{15}$ bicyclic sesquiterpenoid.

The presence of $\mathrm{C}_{15}$-bicyclic sesquiterpenoid compounds according to Philp, (1985) may indicate that oil is formed on land (terrestrial oil) and can be an indicator of the input source of organic matter from higher plants.

The existence of a $4 \beta(\mathrm{H})$-eudesmane compound is identified by having a mass spectrum similar to a cadinane compound. Low relative abundance in ion fragments at m/z 193 and 165 with base peaks at ionic fragments $\mathrm{m} / \mathrm{z} 109$. These compounds can be found in fossil plant tissues, and petroleum extracts together with cadinane compounds. 
Philip, (1985) confirm this compound can be used as an indicator of organic matter source from higher plants.

$4 \beta(\mathrm{H})$-eudesmane also been found in the oil samples Taranaki Basin, New Zealand and is used to see where the role of higher plants in the oil formation [9]. In its present form, this compound is formed from $\beta$-eudesmol as a precursor which is also a typical biomarker of conifer plants that grow in the Devonian era [25]. Therefore, the discovery of $4 \beta(\mathrm{H})$-eudesmane compounds indicates oils derived from higher plants.

The formation of cadinane compounds is originate from cadinene monomer which undergoes hydrogenation into cadinane. The presence of this compound is said to be derived from a precursor of polycadinene which is a component in the dammar resin Angiospermae family Dipterocarpaceae [25]. The fragmentogram of $\mathrm{m} / \mathrm{z} 109$ is indicator of cadinane compound. Biomarkers of cadinane compound is typical of organic matter derived from the Tertiary [15]. The compounds have also been found in the Middle Miocene Epoch rocks source of Brunei Darussalam [23]. Distribution of cadinane compounds produced through pyrolysis of resin of Dipterocarpaceae plant that appears on the surface of the earth in the Miocene Epoch. [26]. Van Aarsen (1992), also reported that cadinane compound indicates input biological of terrestrial materials.

Cadinane compounds formed as a result of the catagenesis process. The burial process and the high temperature cause depolymerization reactions on polycadinane compound. Thus, the cadinane compound formed, as described by van Aarsen et al, (1992). Cadinane compound biomarker indicate that filling material originate from biological materials from Angeospermae family and shown the contribution of organic matter derived from terrestrial. It is also supported by -Concha Kerala shore research in west India that had been done by Dutta and Mallick (2010). This research reported that Dipterocarpaceae is a productive plant vegetations in tropical rain forest with warm conditions during Miocene age. From the previous explanation, it can be conclude that Dipterocarpaceae contribute to the formation of crude oil in Sekar Kurung Gresik.

\section{Biomarkers of pentacyclic triterpenoids}

The hopanoids that identified by mass fragmentogram at $\mathrm{m} / \mathrm{z} 191$ indicate the presence of hopane, bicadinane and gammacerane. The mass fragmentogram is shown in Figure 6.

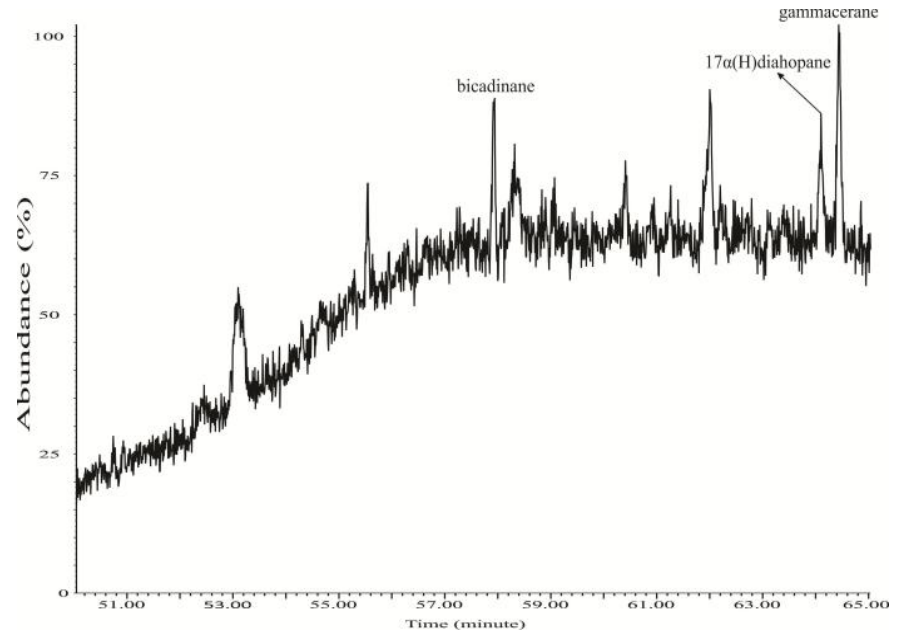

Fig. 6 Mass fragmentogram $\mathrm{m} / \mathrm{z} 191$ aliphatic hydrocarbon fraction.

Hopanoid is pentacyclic triterpenoids biomarkers that indicate environmental conditions of source rock, the origin of organic matter and maturity. Hopanoid compounds are found abundantly in methanotrophic, heterotropic and cyanobacterial bacteria [27] Hopanoid was known as pentacyclic triterpenoids fraction formed from higher plants, it is now more known as pentacyclic triterpene a prokaryotic lipid family. Triterpenes or triterpenoids transformation occured during early diagenesis [28]. The mass spectrum has a base peak at $\mathrm{m} / \mathrm{z} 191$, it was the characteristic of the ion fragment of the A-
$\mathrm{B}$ ring. While the peak of $\mathrm{M}+$ molecule was at $\mathrm{m} / \mathrm{z} 412$, the loss of methyl group $\left(-\mathrm{CH}_{3}\right)$ was indicated by fragment at $\mathrm{m} / \mathrm{z} 397$.

Hopane aliphatic compound fraction was found in the form of pentacyclic triterpenoids that derived from membrane of prokaryotic bacteria cells, $\mathrm{C}_{35}$ bacteriohopanopaliol [27]. The example of these bacteria is bacteriohopanotetrol that dehydrated and reduced during diagenesis that produces bacteriohopane with triterpen in its biomarker. According to Sinninghe-Damste, et al (1995), bacteriohopanoterol enter into kerogen and hydrocarbons hopan was released during catagenesis. Hopane compounds were found in the form of $17 \alpha(\mathrm{H})-$ diahopane and $\mathrm{C}_{30} 17 \alpha(\mathrm{H}) 21 \beta(\mathrm{H})$-hopane $\left(\mathrm{C}_{30} \mathrm{H}_{52}\right)$. Hopane compounds with configuration $17(\alpha), 21(\beta)$-hopane were the most stable isomer configurations. The hopane skeleton initially has a $17 \beta$ (H) $21 \beta(\mathrm{H})$ isomer configuration which is less stable. As the temperature increases, the molecule stereochemistry was transformed toward a more stable isomer of $17 \beta(\mathrm{H}) 21 \alpha(\mathrm{H})$, and eventually reaches the most stable isomer of $17 \alpha(\mathrm{H}) 21 \beta(\mathrm{H})$ [29]. Based on hopane compound biomarker analysis of the $\mathrm{C}_{30}$ the contribution of bacteria to organic materials can be studied. The existence of hopane with $\alpha \beta$ configuration give information that the crude oil from Sekar Kurung Gresik was mature.

Another triterpenoid compound that observed was bicadinane. The presence of bicadinane compounds is identified by $\mathrm{m} / \mathrm{z} 191$ fragments in Figure 6. The interpretation of the mass spectrum of this compound was compatible with the compounds that have been reported by van Aarsen et al. (1992). The bicadinane as well as hopane and sterane compound have base peak at $\mathrm{m} / \mathrm{z} 191$ The bicadinane compound has high abundance at $\mathrm{m} / \mathrm{z} 369$ and 412 . According to Peters et al. (2005) that have studied the peak at $\mathrm{m} / \mathrm{z} 369$ and 412 , but can be distinguished by looking at retention times, hopane compounds have higher retention time than bicadinane compounds.

The presence of bicadinane compounds shows the presence of plant resins of the Dipterocarpaceae family. The precursor of this compound was abundant in policadinene polymer resin of Angiospermae plant [30]. The analysis of bicadinane biomarker compounds and their derivatives, confirm the previous biomarker studies, that the dammar resin of Angiospermae family, Dipterocarpaceae, contributes to organic compounds in Sekar Kurung Gresik crude oil. The stage of its formation revolves around the Miocene era.

Gammacerane is a pentacyclic triterpenoids biomarker, compiled a number of six-ring with $\mathrm{C}_{30} \mathrm{H}_{52}$ formula which is generally associated with high salinity environments such as sea or lake environments [28;29]. Gammacerane has been identified in shale, oil and sediment [31]. Gammacerane was derived from the reduction of tetrahymanol [32], and earlier studies suggested it was derived from protozoan tetrahymena [27]. Later, researches found the source of tetrahymenol, the precursor of gammacerane, Gammacerane in relatively small quantities indicate that the environmental deposition conditions was on the ground with low salinity levels $(<0.05 \%)$. This is because in these conditions, some organisms such as bacteria phototropic produce tetrahymanol [29].

Gammacerane compound was the contribution of protozoa [18]. Gammacerane is a typical biomarker for marine or terrestrial deposition environment with certain salinity levels, indicating that the origin of crude oil Sekar Kurung Field are formed from phototropic bacteria in the deposition conditions with low salinity levels.

\section{Biomarkers of sterane}

Sterane in the range of $\mathrm{C}_{27}-\mathrm{C}_{29}$ were used extensively in petroleum geochemistry to determine the relationship and determination of the oils source. Sterane existence in fossil fuels were derived from a complex mixture of sterols produced by plants, animals and other organisms. Sterane formation from sterol requires a number of sterene and steradiene as an intermediate [18]. Sterane and sterena were originate from sterols and eukaryotic cell membranes, especially algae and higher plants. Its presence was more common in marine sediments but not in the source rock or crude oil. Therefore, sterane and diasterane also present in fossil fuels [28].

Sterane were considered as the primary source of eukaryotic organisms in sediments [27]. The distribution of sterane and diasterane 
is identified by mass fragmentogram at $\mathrm{m} / \mathrm{z} 217$ (Figure 7), which is typical in the series of sterane [18].

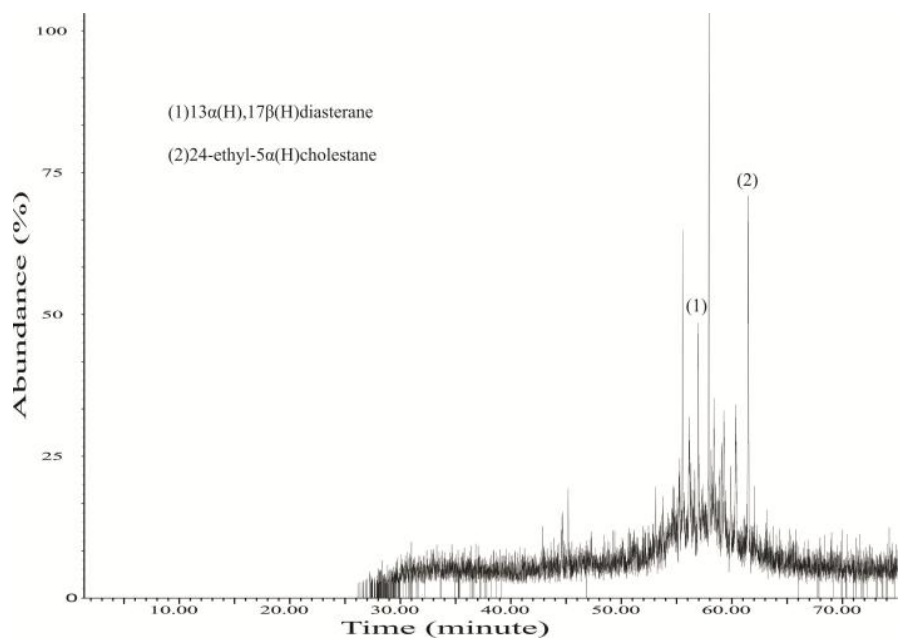

Fig. 7 Mass fragmentogram $\mathrm{m} / \mathrm{z} 217$ aliphatic hydrocarbon fraction.

In this sample, compounds $13 \alpha(\mathrm{H}) 17 \beta(\mathrm{H})$ diasterane, 24-ethyl$5 \alpha(\mathrm{H})$ cholestane were identified. The $13 \alpha(\mathrm{H})-17 \beta(\mathrm{H})$-diasterene compound was derived from sterols $\mathrm{C}_{28}$ formed from phytoplanton namely green algae and 24-ethyl-5 $\alpha(\mathrm{H})$ cholestane that derived from terestrial plant $[18]$.

\section{CONCLUSION}

Aliphatic hydrocarbon biomarker compounds e.g. $n$-alkanes $\left(\mathrm{C}_{14-}\right.$ $\left.\mathrm{C}_{28}\right)$, acyclic isoprenoid $\left(\mathrm{iC}_{15}, \mathrm{iC}_{16}\right.$ and $\left.\mathrm{iC}_{18}-\mathrm{iC}_{20}\right)$, bicyclic sesquiterpane, eudesmane, cadinane, hopane compound $\left(\mathrm{C}_{30}\right)$, bicadinane, gammacerane, and diasterane $\left(\mathrm{C}_{27}-\mathrm{C}_{29}\right)$ were obtained from analysis of aliphatic fractions in Sekar Kurung Gresik crude oil. The identification of aliphatic biomarker compounds show that crude oil were mature oil that derived from high plants, the contribution of bacterial activity as well as oxic deposition environment $(\mathrm{Pr} / \mathrm{Ph}=5.3$ $(>1))$.

\section{ACKNOWLEDGEMENT}

The authors thank to Head of the Laboratory of Molecular Geochemistry Department of Chemistry, Faculty of Mathematics and Natural Sciences Institute of Technology, for the opportunity to conduct this research.

\section{REFERENCES}

[1] Wang, Z., Yang, C., Yang, Z., Brown, C. E., Hollebone, B. P., Stout, S. A (2016). Petroleum biomarker fingerprinting for oil spill characterization and source identification. In Standard Handbook Oil Spill Environmental Forensics, Stout ( $2^{\text {nd }}$ Edition), Stout, S. A. and Wang, Z. (Eds.), Academic Press, pp. 131.

[2] Ji-Yang, S., Meckenzie, A. S., Alexander, R., Eglinton, G., Gowar, A. P., Wolff, G. A. and, Maxwell, J. R. (1982). A biological marker investigation of petroleum and shales from the Shengli oilfield. The People's Republic of China, Chemical Geology, 35, 1-31.

[3] Simoneit B. R. T. (2004). Biomarkers (molecular fossils) as geochemical indicators of life. Advances in Space Research 33, 1255-1261.

[4] Grass, G. V. (1986). Biomarker distributions in aspaltenes and kerogens analysed by flash pyrolysis-gas chromatography- mass spectrometry. Organic Geochemistry. 10,1127-1135.

[5] Hughes, W. B., dan Holba, A. G. (1988). Relationship between crude oil quality and biomarker patterns. Organic Geochemistry, 13, 15-30.

[6] Burhan, R. Y. P dan Zetra, Y, Albrecht, P. (1997). Pengkajian senyawa penanda biologik pada aspal Laut Mati. IPTEK 8, 122-129.

[7] Philp, R. P., Mansuy, L. (1997). Petroleum geochemistry: Concept, application and result. Energy and Fuels, 11(4), 749-760.

[8] Didyk B. M., Simoneit, B. R. T., Brassell, S. C., Eglinton, G. (1978). Organic geochemical indicators of palaeoenvironmental conditions of sedimentation. Nature 272, 216-222.
[9] Weston, R. J., Philp, R. P., Sheppard, C. M., Woolhouse, A. D. (1989). Sesquisterpanes, diterpanes and other higher terpanes in oils from the Taranaki Basin of New Zealand. Organic Geochemistry, 14, 405-421.

[10] Sonibare, O. O., and Ekweozor, C. M. (2004). Identification of bicyclic sesquiterpanes in oils from the Niger Delta, Nigeria. Jurnal of Applied Sciences 4(3), 508-512.

[11] Wilson, M. E. J, dan Hall, R. (2010). Tectonic influences on Se Asian carbonate systems and their reservoir development. SEPM (Society for Sedimentary Geology), 13-40.

[12] Ourisson, G., Albrecht, P. and Rohmer, M. (1984). The microbial origin of fossil fuels. Scientific American, 251(2), 44-51.

[13] Philp, R. P. (1986). Biomarker distributions in Australian oils predominantly derived from terrigenous source material. Organic Geochemistry 10, 73-84.

[14] Yuanita, E., Burhan, R. Y. P. dan Wahyudi. (2007). Biomarka hidrokarbon alifatik sedimen Laut Arafura Core MD 05-2969. Akta Kimindo 2, 99-102.

[15] Lu, X., and Zhai, S. (2006). Distributions and sources of organic biomarkers in surface sediments from the Changjiang (Yangtze River) Estuary, China. Continental Shelf Research 26, 1-14.

[16] Richarson, J. S., and Miller, D. E. (1982). Identification of dicyclic and tricyclic hydrocarbons in the saturate fraction of a crude oil by gas chromatography-mass spectrometry. Analytical Chemistry, 54(4), 765768.

[17] van Aarsen, B. G. K, and Hessels, J. K. C., Abbink, O. A., De Leeuw, J. W. (1992). The occurrence of polycyclic sesqui-, IS-, and oligoterpenoids derived from a resinous polymeric cadinene in crude oils from southeast Asia. Geochimia et Cosmchimica Acta, 56, 1231-1246.

[18] Philp, R. P. (1985). Fossil fuel biomarker, applications and spectra. Methods in Geochemistry and Geophysics, pp. 196.

[19] Brooks, J. D., Gould, K., Smith, J. W. (1969). Isoprenoid hydrocarbons in coal and petroleum. Nature, 222, 257-259.

[20] Johns, R., Belsky, T., McCarthy, E., Burlingame, A., Haug, P., Schnoes, H., Richter, W., and Calvin, M. (1966). The organic geochemistry of ancient sediments - Part II. Geochimica et Cosmochimica Acta, 30, 11911222.

[21] Philp, R. P., Gilbert, T. D., and Friedrich, J. (1981). Bicyclic sesquiterpenoids and diterpenoids in Australian crude oils. Geochimica et Cosmochimica Acta, 45(7), 1173-1180.

[22] Alexander, R., Kagi, R. I., Noble, R., and Volkman, J. K. (1984). Identification of some bicyclic alkanes in petroleum. Organic Geochemistry, 6, 63-72.

[23] Eiserbeck, C., Nelson, R. K., Grice, K., Curiale, J., Reddy, C. M. (2012). Comparison of GC-MS, GC-MRM-MS and GCxGC to characterize higher plant biomarkers in tertiary oils and rock extracts. Geochimica et Cosmochimica, 87, 299-322.

[24] Morley, R. (2000). Origin and evolution of tropical rain forest. New York, Wiley-Blavkwell, pp. 61.

[25] van Aarsen, B. G. K., Cox, H. C., Hoogendoorn, P., DeLeeuw, J. W. (1990). A cadinene biopolymer in fossil and extant dammar resins as a source for cadinanes and bicadinanes in crude oils from South East Asia. Geochimica et Cosmochimica Acta 54, 3021-3031.

[26] Widodo, S., Bechtel, A., Anggayana, K., Püttmann, W. (2009). Reconstruction of floral changes during deposition of the Miocene Embalut coal from Kutai Basin, Mahakam Delta, East Kalimantan, Indonesia by use of aromatic hydrocarbon composition and stable carbon isotope ratios of organic matter. Organic Geochemistry, 40, 206-218.

[27] Ourisson, G., Albrecth, P., Rohmer, M. (1984). The hopanoids - The palaeochemistry and biochemistry of a group natural product. Pure and Applied Chemistry, 51, 709-729.

[28] Waples, D. W., and, Machihara, T. (1991). Application of steranes and triterpanes in petroleum exploration. Bulletin of Canadian Petroleum Geology, 38(3), 357-380.

[29] Peters, K. E., and, Moldowan, S. M. (1993). The biomarkers guide interprenting molecular fossil in petroleum and ancient sediment. Prentice Hall Inc., New Jersey, pp.160

[30] Armanios, C., Robert, A., Sosrowidjojo, I. B., Kagi, R. I. (1995). Identification of bicadinanesin Jurassic organic matter from the Eromanga Basin, Australia. Organic Geochemistry, 23, 837-843.

[31] Bendoraitis, J. G. (1973). Hydrocarbons of biogenic originin petroleumaromatic triterpenes and bicyclic sesquiterpenes. In: Tissot, B., and Bienner, F. (Eds.), Adv. In Organic Geochemistry, Editions Technip, Paris, pp. 209-224

[32] Venkatesan, M. I. (1989). Tetrahymanol: Its widespread occurrence and geochemical significance. Geochimica et Cosmochimica Acta, 53(11), 3095-3101.

[33] Burhan R. Y. P. (2002). Biomarka panduan bagi peneliti bumi, ITS Press, pp. 28-38.

[34] Erbacher, J., Mosher, D. C., M. J. (2004). Molecular biogeochemistry of cretaceous black shales from the Demerara rise: Preliminary shipboard 
results from sites 1257 and 1258, ODP leg 207, Proceedings of the Ocean Drilling Program 207, 1-22.

[35] Bakar, N. A., Tay, K. S., Omar, N. Y. M. J., Abas, M. R. B., Simoneit, B R. T. (2011). The geochemistry of aliphatic and polar organic tracers in sediments from Lake Bera, Malaysia. Applied Geochemistry, 26, 14331445 .

[36] Sinninghe Damsté, J. S., Rijpstra, W. I. C., Schouten, S., Fuerst, J. A., Jetten, M. S. M., and, Strous, M. (2004). The occurrence of hopanoids in planctomycetes: Implications for the sedimentary biomarker record. Organic Geochemistry, 35, 561-566.

[37] Tissot, B. P., and, Walte, D. H. (1984). Petroleum formation and occurence. Spinger, Verlag: Berlin, pp. 100

[38] Zhang, Z., Zhao, M., Yang, X., Wang, S. (2004). A hydrocarbon biomarker record for the last $40 \mathrm{Kyr}$ of plant input to Lake Heqing, soutweatern China. Organic Geochemistry, 3, 595-613.

[39] Zinniker, D. A., and Moldowan, J. M. (2005). New insight into molecular fossil: The fate of terpenoids and the origin of gem-dialkylalkanes in the geological environment. Stanford University.

[40] Schefub, E., Ratmeyer, V., Stuut, J. -B., Fred Jansen, J. H., Sinninghe Damste, J. S. (2003). Carbon isotop analyses of n-alkanes in dust from the lower atmosphere over the central eastern Atlantic, Geochimica et Cosmochimica Acta, 67(10), 1757-1767.

[41] Hsu, C. S., Walter, C. C., Isaksen, G. H., Schaps, M. E., Peter, K. E. (2003). Biomarker analysis in petroleum exploration, Analytical Advances for Hydrocarbon Research, pp. 223-225.

[42] Hakimi, M. H., Ahmed, A. F., Abdullah, W. H. (2016). Organic geochemical and petrographic characteristics of the miocene salif organic-rich shales in the Tihama Basin, Red Sea of Yemen; Implications for paleoenviromental conditions and oil - Generation potential. International Journal of Coal Geology, 154-155, 193-204.

[44] Sinninghe Damste, J. S., Hollander, D., Kohnen, M. E. L., de Leeuw, J. W. (1995). Early diagenesis of bacteriohopanetetrol derivates; Formation of fosisil homohopanoids, Geochimica et Cosmochimica Acta, 59(24), 5141-5157.

[45] Herod, A. A., Hellenbrand, R., Xu, B., Zhang, S., Kandiyoti, R., (1995), Alkanes and solvent dimers in successive extract fractions released from coal during liquefaction in a flowing solvent reactor, Fuel, 74(12), 1739. 1752 . 